\title{
Our shifting perspectives on the oceans
}

\author{
Callum M. Roberts
}

\begin{abstract}
In the last 15 years new research findings have radically reshaped our understanding of human effects on ocean ecosystems. Here I describe five major shifts in perspective that reveal our impacts to be more severe and persistent than previously appreciated. Firstly, scientists have delved deep into the past and found that the global expansion of European nations across the planet caused the large-scale loss of marine megafauna. In the past century, expansion of industrial scale fishing has continued the process, massively reducing the biomass of exploited species. Secondly, once depleted we are finding that populations rarely rebound rapidly, contrary to a widespread belief in greater resilience of marine compared to terrestrial species. Thirdly, marine ecosystems are being shifted into alternative states that are less desirable from the human perspective and may be stable. It could be difficult, or impossible in some
\end{abstract}

cases, to reverse impacts once inflicted. Fourthly, marine species are at risk of extinction. Loss of shallow water marine habitats is proceeding as rapidly as on land, many species have small geographic ranges, and many possess life history characteristics that leave them highly susceptible to overexploitation. Finally, the deep sea is not beyond harm. Depletion of shallow water fisheries and technological advances are opening up the deep to exploitation and its collateral impacts. If we are to reverse these negative trends we must establish largescale networks of marine reserves that are off limits to damaging activities and fishing. Such reserves would protect biodiversity, and recover and sustain the world's fisheries productivity.

Keywords Extinction, fisheries, marine ecosystems, marine reserves, oceans, overexploitation.

\section{Introduction}

Long ago people thought of the oceans as a limitless expanse, stretching far beyond the horizon to unknown places. Over the last 1,000 years, explorers confirmed the enormity of the oceans, and brought back stories of abundant marine life. It seemed that the sea was a boundless resource that we could tap at our will. With the oceans covering $71 \%$ of the surface of the planet and $>95 \%$ of the volume of the biosphere (Angel, 1993) many people have carried on thinking that way. Mistakenly, they believe that problems affecting the sea are more minor than on land, and conclude that the sea deserves less attention from politicians, managers and conservationists.

Such views are changing. In this paper, I explore five facets of the recent revolution in our understanding of the oceans: (1) Our perspective is growing longer; we now realize that the seas are not what they once were, and that there is little left that can be considered natural. (2) Species do not always recover after depletion. Marine

Callum M. Roberts Environment Department, University of York, York, Y010 5DD, UK. E-mail: cr10@york.ac.uk

Received 4 March 2003. Revision requested 8 April 2003. Accepted 14 April 2003 species are no more resilient to human assault than those that live on land. (3) Marine ecosystems can be transformed into less desirable states that may be stable. (4) Species in the sea are at risk of extinction; habitat loss and transformation in shallow seas are as rapid and extensive as on land, many species are narrowly distributed, and exploitation increases risk of disappearance.

(5) The deep sea is not safe from harm.

With hindsight, none of this should surprise us. These problems have long been recognized above water. While there are many contrasts between land and sea, that the creatures of the ocean dance to the same music as those on land should not astonish us given their shared evolutionary history. Given our propensity for expansion and record of subjugating nature, it should have been obvious that it was only a matter of time before the seas came under our influence. But this paper is not intended as yet another grim accounting of the declining state of our planet. Admittedly, there is bad news to relate, but I end on an optimistic note. There is much that we can do to protect the oceans. We have promising tools that could help undo the harm already done and foster resilience against future damage. With the oceans still being common property our options are arguably broader than on land. We have more leeway to take the necessary steps to protect marine life. 


\section{Our perspective grows longer}

In 1741 Georg Wilhelm Steller, naturalist and doctor aboard Vitus Bering's last voyage of discovery through the far northern Pacific, was shipwrecked on the remote Commander Islands in the west Bering Sea (Steller, 1743). The giant sea cows there so impressed him by their abundance that he declared they could feed all the people of Russia's Kamchatka peninsula. Twenty-seven years later they were extinct: the first marine species to be destroyed by people. Unwittingly, Steller was probably responsible for the rapidity of their demise. In his account of the voyage, he described their great value as provision for sailors and their ease of capture. Perhaps the fatal detail was his comment that their oil acted as a preventative and a treatment for scurvy, the scourge of early exploration.

Exploitation of the seas has its roots in exploration. Early explorers writing about oceans teeming with life encouraged a second wave of global travel, spearheaded by merchants seeking profit. William Dampier, navigator, pirate, sea captain, diplomat, naturalist, author and relentless traveller, exemplifies this age of first encounter. For example, in his A New Voyage Round the World, published to huge acclaim in 1697, he writes concerning seals of the isle of Juan Fernandez, far off the Chilean coast: "Here there are always thousands, I might say millions of them, either sitting on the bays, or going and coming in the sea round the island, which is covered with them (as they lie at the top of the water playing and sunning themselves) for a mile or two from the shore... A blow on the nose soon kills them. Large ships might here load themselves with seal-skins, and Trane-oyl [oil extracted from blubber]; for they are extraordinary fat" (Dampier, 1697).

The process of subduing the oceans began with the hunting of megafauna such as seals, manatees, turtles and whales (Jackson, 1997; Jackson et al., 2001). Our own generations grew up knowing only seas that had already lost so much life they would be almost unrecognizable to sailors of Dampier's day. Jackson (1997) estimates that at the time of Columbus's voyage to the Caribbean in 1492, there could have been as many as 33 million turtles there. Certainly, in his pirating days, Dampier and his companions dined lavishly on turtle and manatee. He notes that most ships in the region carried aboard two or three Central American Miskito Indians for their expertise in 'striking' turtle, manatee and large fish.

In some places fishing vessels were part of the first wave of exploration, in others they followed swift on the heels of explorers. For example, when John Cabot claimed Canada for England in 1497, he probably found Basque fishermen already exploiting the vast abundance of cod Gadus morhua in the seas of eastern North America, although he didn't mention this embarrassing observation in his dispatches to the king (Kurlansky, 1997). The Dutch were shipping anchovies from South Africa to Europe by the late 1600s (Dampier, 1697). What has happened to fisheries since is a familiar story. In a replay of terrestrial history people first exploited big animals (in the sea often upper trophic level predators), moving from one to another and from place to place as populations were depleted and eventually extirpated (Cushing, 1988). Exploration gave way to exploitation and the pattern went from small-scale to industrial fisheries, from high to low value species, and from abundance to scarcity (Jackson et al., 2001).

Christensen and colleagues (Christensen et al., 2003) have documented the final stages of exploitation in the North Atlantic. They used a combination of catch records and trophic models to describe the decimation of food fish stocks over the last 100 years (Fig. 1). There has been a dramatic collapse in the biomass of higher trophic level species. In the days of John Cabot and the Basque fisheries, cod were as abundant and important in these marine ecosystems as the great herds of buffalo were on the American plains. Today, with their predators all but gone, crustaceans now comprise the most valuable component of catches.

\section{Species do not always recover after depletion}

There is a common misconception that marine species are more resilient to disturbance and human assault than terrestrial ones. The notion is deeply ingrained and is exemplified by an entry on cod in the 1858 edition of the Encyclopedia of Commerce and Commercial Navigation: "Cod - a species of fish too well known to require any description. It is amazingly prolific. Leewenhoek counted 9,384,000 eggs in a cod fish of a middling size - a number that will baffle all the efforts of man to exterminate" (quoted in Kurlansky, 1997). The extreme fecundity of many marine species is frequently taken as evidence enough that depleted species can bounce back if we relax the intensity of exploitation. The concept of 'compensation', which predicts an increase in population growth rate at smaller population sizes, is one of the central tenets of fisheries science. However, this is based on the assumption that there are excess offspring around that will survive when stocks are reduced in size (Jennings et al., 2001).

Despite there being only weak evidence that population growth rates do increase at low stock sizes (Jennings et al., 2001), the view remains strong that marine species differ in this respect from land animals (Hutchings, 


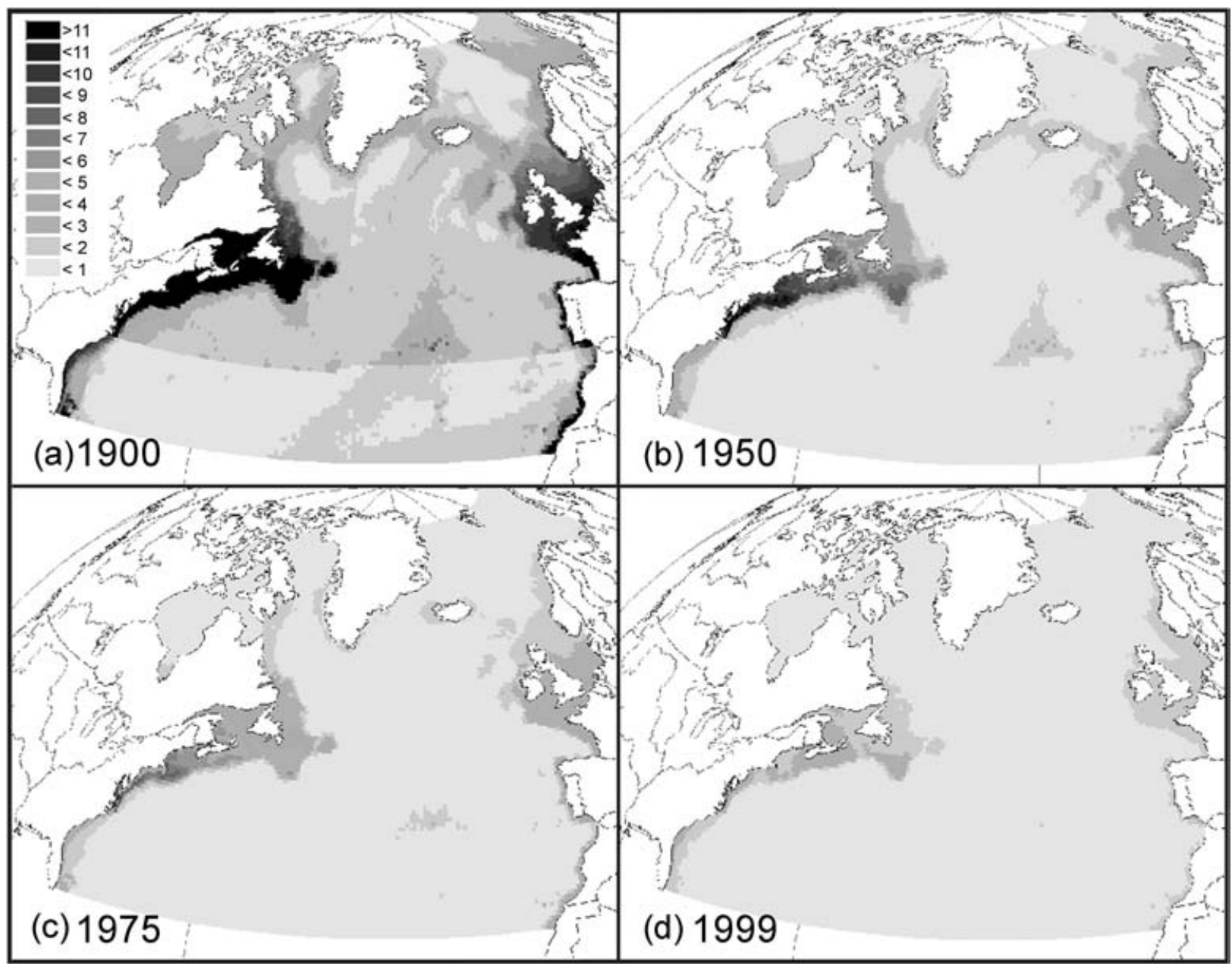

Fig. 1 Change in biomass (tonnes $\mathrm{km}^{-2}$ ) of tablefish (the major fish species exploited for human consumption) in the North Atlantic during the 20th Century. Reproduced from Christensen et al. (2003) with permission.

2000). The American Fisheries Society has adopted higher thresholds for population decline in marine species than those used by the IUCN for categorizing threatened species. Thresholds for the IUCN Red List require declines over 10 years or three generations exceeding $30 \%$ for a species to be Vulnerable, $50 \%$ for it to be Endangered, and 80\% for Critically Endangered (IUCN, 2001). The corresponding American Fisheries Society thresholds range between a $70 \%$ decline in 10 years or three generations for species classified as low productivity, and a 99\% decline for species considered highly productive (Musick, 1999). The Food and Agriculture Organization of the United Nations, the global body responsible for monitoring fisheries stocks, recently argued that listing marine species under the population decline criterion of CITES (The Convention on International Trade in Endangered Species), i.e. a $\geqslant 50 \%$ decline of a species in 5 years, would produce too many false alarms and cause unnecessary economic hardship (FAO, 2000).
Hutchings (2001) examined the evidence for recovery of 90 fish stocks after severe depletion. He found that only a handful of stocks made a full recovery after efforts to reduce fishing mortality. For the 25 stocks for which 15 years of post-decline data were available, only $12 \%$ made a full recovery, all of them clupeids (species including herring and sardines). Forty percent of species experienced no recovery at all after this period, and most others made little recovery. Hutchings (2000) attributes the resilience of clupeids to their early maturity, which he suggests is an adaptation to life in highly variable pelagic ecosystems that allows populations to track temporal and spatial fluctuations in food supply.

There are many reasons why species fail to recover. One is that populations may be unable to reproduce effectively at low population densities (Allee effects). For example, species like giant clams (Tridacna) on IndoPacific coral reefs reproduce by releasing eggs and 
sperm into the water column. But clams are literally rooted to the spot and rely on densities being high so that they are close enough together for fertilization to be successful. The largest clam species Tridacna gigas has become extinct in Fiji, Guam, New Caledonia and the Northern Marianas islands, probably because densities were reduced by fishing below thresholds necessary for successful reproduction (Wells, 1997).

Depletion may also rob species of traits critical to their previous success. For example, before we destroyed them, cod migrations ranked among the wonders of our planet. With the arrival of warmer spring weather in eastern North America, enormous cod shoals would move in from deep water, following submarine canyons running from the continental shelf edge to the coastal shallows where they spawned. The biggest, oldest fish would lead the shoals, probably passing knowledge of traditional migration routes to younger fish (Rose, 1993). Northern cod stocks have languished at a fraction of their former abundance since the 1992 Canadian moratorium on cod fishing, and some populations have not recovered since depletion in the 1960s (Smedbol \& Wroblevski, 2002). It is conceivable that lost knowledge of these migration routes may be contributing to this lack of recovery.

Species may also fail to recover because their depletion changes the rules of the game. By this I mean that processes that had little influence before depletion may assume much greater importance when a species becomes rare. In the Caribbean, for example, the staghorn coral Acropora cervicornis illustrates how changing species interactions can hold back recovery. This coral once dominated shallow water reefs (Jackson, 1997), until a disease epidemic in the mid 1980s reduced populations throughout the Caribbean by more than 95\% (Bythell \& Sheppard, 1993). Staghorn corals are territory for threespot damselfish Stegastes planifrons. Their complex 3-dimensional branching structure is ideal for these fishes' algal gardens, allowing them to defend the maximum amount of algae in a minimum amount of space. In St Lucia electivity indices showed that staghorn corals were the most preferred by Stegastes planifrons. However, they constitute less than $1 \%$ of the total coral cover (T. McGarry \& C. M. Roberts, unpubl. data), making it extremely hard to find any colony not covered in algal lawn. These lawns compromise the reproductive output of the little staghorn coral that remains. When this coral was abundant there was far more of it than the damselfish could use and so the relationship had little impact (Precht et al., 2002). However, now the damselfish could be keeping the coral rare and even threatening its long-term survival.

Finally, habitat modification may inhibit recovery. For example, intensive trawling rapidly shifts seabed habitats from being dominated by exposed epifauna, such as corals, bryozoans, hydroids and crinoids, to dominance by small infauna, such as nematode and polychaete worms (Collie et al., 1997; Watling \& Norse, 1998; Bradshaw et al., 2001). Consequently it reduces habitat complexity, biomass and diversity of bottomliving communities. Juvenile fish often survive better in structurally complex habitats than in simple ones, because such habitats offer refuges from predators and better feeding conditions (e.g. Auster \& Langton, 1999; Lindholm et al., 1999). While trawling continues, recovery may be prevented by the habitat change it induces.

\section{Marine ecosystems are being shifted into less desirable states}

The case of cod highlights another problem in the oceans: marine ecosystems are changing in ways that make them less beautiful, less productive of the things we value, and less safe for us. Some of these altered states appear to be stable, and will be difficult to reverse. At the time of Cabot's voyage, marine ecosystems of the Grand Banks of Canada were among the richest and most productive in the world. Intensive overfishing eventually eliminated cod in the early 1990s, triggering the fishing moratorium mentioned above. Fishers seeking alternatives switched to lobsters and capelin Mallotus villosus. Capelin are a major forage fish for cod, and it is possible that cod will never recover to their former numbers while fishers target their prey (Rose \& Driscoll, 2002).

Jackson et al. (2001) argue that some disease epidemics in the oceans have their origins in the destruction of aquatic fauna by fishing and hunting. For example, they point to the disease that caused a mass seagrass die off in Florida Bay. While others attribute such effects to pollution or climate change (e.g. Harvell et al., 1999); Jackson et al. (2001) argue that when turtles were abundant in the Caribbean, they cropped the seagrass short. The virtual loss of turtle grazing increased the biomass of turtle grass that promoted the accumulation of rotting tissue that formed the foci for infection.

Another example offered by Jackson et al. (2001) concerns Chesapeake Bay on the US east coast. When European ships first landed in Virginia, Chesapeake was so full of oyster reefs that they were hazardous to navigation. In terms of their ability to filter Chesapeake's water, Jackson et al. have estimated that they could do this about every three days. Now, after more than 100 years of intensive dredging the oyster reefs have all but been destroyed and it could take hundreds of days for those remaining to filter the bay's waters. In recent years, Chesapeake has suffered an increasing frequency 
and intensity of harmful algal blooms (Fleming et al., 1999; Zimmerman \& Canuel, 2000), including the highly toxic dinoflagellate Pfiesteria (Burkholder et al., 1999). Previously, such blooms were blamed entirely on pollution from upstream cities and agriculture, but Jackson et al. (2001) have mustered data suggesting that increases in pollution preceded the incidence of algal blooms, and that these only became a problem once oysters had been destroyed.

This new oyster-less state appears stable. With algal blooms, expanding regions of anoxic water have afflicted the bottom of Chesapeake Bay. Lenihan \& Peterson (1998) have shown how reefs have been dredged to depths below the upper levels of anoxic water, so killing oyster spat that could otherwise facilitate recovery. Losing these reefs may also promote the development of anoxic regions, by reducing turbulent mixing of bay waters.

There are many other examples of unwelcome changes in marine ecosystems around the world. Mucilaginous plankton clogs fishing nets and afflicts beach resorts in the Adriatic (Thornton et al., 1999), jellyfish invading the Black Sea reduced fishery production there (Knowler \& Barbier, 2000), and coral reefs have been transformed from coral to algal dominance (Done, 1992). Fig. 2 shows Jackson et al.'s (2001) summary of the sequence of such changes to marine ecosystems. Fishing was the first of a series of human impacts on the sea, and has been succeeded over time by others including pollution, mechanical habitat destruction, introduced species and lastly, climate change. The state of our oceans today is a result of a complex interplay of these impacts, but Jackson et al. (2001) argue that fishing has played a central role in the degradation of ocean ecosystems.

\section{Species in the sea are at risk of extinction}

Viewed from the surface, the sea appears unchangeable. On a clear day, the Caribbean looks as radiant and blue

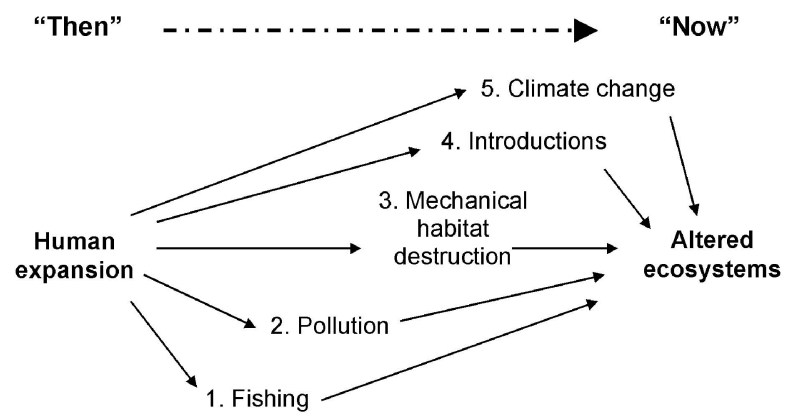

Fig. 2 Historical sequence of human impacts on marine ecosystems. Reproduced from Jackson et al. (2001) with permission. to us today as it would have appeared to Columbus and his crew. But this beauty and apparent constancy conceal what lies beneath. In reality, habitat loss and transformation in shallow seas is now as rapid and extensive as on land.

Trawling, as I have already mentioned, is the most extensive and long-standing agent of destruction and change. Watling \& Norse (1998) estimate that an area equivalent to half of the world's continental shelves is trawled every year, a rate that is $>150$ times the rate of forest clearcutting on land. Other agents of habitat loss affecting the sea include pollution, deforestation, conversion to other uses such as agriculture and ports, and climate change. Coastal habitats are being destroyed at alarming rates, often to make way for development or aquaculture. For example, we have already lost over half the world's mangrove forests and saltmarshes, and in some countries, losses have reached over $75 \%$ (Spalding et al., 1997).

A recent estimate suggested that $11 \%$ of coral reefs have been destroyed by human activities (Wilkinson, 2000), but global warming is now rapidly increasing that toll. In 1998 the Indian and Pacific Oceans experienced the most intense episode of sea-surface warming yet recorded (Hoegh-Guldberg, 1999). This put coral reefs under severe stress, causing widespread coral bleaching, a process where corals lose or expel the symbiotic plants that inhabit their tissues. Because these plants supply corals with food, prolonged bleaching will kill them, and the event killed $70-95 \%$ of corals throughout vast swathes of the Indian Ocean. This took the global area of reef destroyed to c. 25\% (Wilkinson, 2000). Of course, much of this will recover, but climate models predict an increase in the frequency, intensity and duration of sea-surface warming, suggesting a very uncertain future for reefs and their inhabitants (Hoegh-Guldberg, 1999).

On land, habitat loss is a sure indication that species are being driven to extinction (Pimm \& Raven, 2000). But we have been cavalier about the possibility of species in the sea becoming extinct. Since the early days of the 19th century, scientists have assumed that marine species such as fish and invertebrates are almost impossible for us to destroy (Carlton et al., 1999; Roberts \& Hawkins, 1999; Reynolds et al., 2002; Dulvy et al., in press). Because many of them produce planktonic offspring that can drift long distances on ocean currents, marine species have been assumed to be more widespread than those on land and so less at risk of extinction from localized human impacts.

This comforting assumption is simply not true. Roberts et al. (2002) recently mapped the geographic ranges of more than 3,000 species of fish, corals, snails and lobsters that inhabit coral reefs. They discovered 
that many had very small ranges. More than half of all lobsters and a quarter of fish and snail species had ranges encompassing $<500,000 \mathrm{~km}^{2}$ of ocean. Among corals, $7.2 \%$ were unique to areas no greater than this size. Although such ranges may seem large, they equate to an average of under $3,500 \mathrm{~km}^{2}$ of reef habitat. This is equivalent to the area of a single coral atoll $66 \mathrm{~km}$ across.

Moreover, just like terrestrial species, in the sea restricted range species are clustered into small geographic regions. Roberts et al. (2002) identified 10 hotspots of biodiversity in places highly threatened by human activities and concluded that potential for marine extinctions is high. This also seems to apply to some parts of the deep sea, although our knowledge of deepwater habitats is very limited. In one study, 30\% of species from Southern Ocean seamounts appeared to be restricted to closely spaced ranges of underwater peaks (De Forges et al., 2000).

Analyses of extinctions in the sea suggest that estuarine environments are already hotspots of species loss, suffering as they are from the dual onslaught of pollution and development (Roberts \& Hawkins, 1999). Overexploitation adds to losses driven by habitat destruction. Brashares et al. (2001) recently reported from West African forest reserves that extinction rates of species that are hunted were 14-307 times greater than predicted by species-area relationships. Many fish and invertebrates are intensively exploited over broad geographic regions. Numerous large-bodied species have already been extirpated from broad areas of their former ranges (Wing \& Wing, 2001; Hawkins \& Roberts, in press). Unless we act decisively the 21st Century will see a wave of extinctions in the sea caused by humanity's recklessness.

\section{The deep sea is not safe from harm}

The deep sea is one of the world's last great wildernesses. Not long ago it appeared more remote and mysterious than the moon. We still know very little about what goes on in the depths of the oceans. As yet biological science has only touched upon one millionth of the deep sea floor (Angel, 1993), but new technologies are providing keyhole glimpses into the abyss and revealing unknown and exotic habitats as quickly as we look (Van Dover et al., 2002). Remoteness no longer protects the deep sea from human interference or the devastating reach of industry.

Rapid technological advances and escalating fishing pressure, especially in the last 50 years, have opened up vast tracts of deep ocean to exploitation. Today, fishing vessels routinely trawl to depths of $1,500 \mathrm{~m}$, and experimental fishing programmes delve beyond 2,000 m. Fishing boats have gear that now penetrate into areas once considered too rough for fishing, and trawls are able to move rocks measuring up to $3 \mathrm{~m}$ in diameter and weighing 16 tonnes (McAllister et al., 1999). In addition to improving on technologies such as nets and boats, we have recently gained a far more lethal edge to our assault on the sea.

The 'peace dividend' from the end of the Cold War has led to civilian applications for military technologies developed for submarine warfare and espionage. These transferred technologies include sonar mapping systems that reveal every crack and contour of the seabed in exquisite detail. The US Geological Survey, for example, is publishing maps that enable fishers to penetrate deep into regions once thought impossible for fishing. Private companies are also weighing in, selling the secrets of the seabed for short-term profit. Guided by precision satellite navigation systems, fishers can now drop nets into previously unseen canyons, or land hooks on formerly uncharted seamounts. Such places may be the last refuges of species such as skates and rockfish that have been decimated by fishing. They are also the last redoubts of complex and unique communities that have developed undisturbed for millennia.

Deep-sea habitats are completely inappropriate for fisheries exploitation. In the deep sea, fishing gear is encountering species and habitats that have far less ability to bounce back than those living in the 'fast lane' of shallow seas. The almost glacial pace of life in the deep makes it a particularly unsuitable place to fish. Many species grow slowly and live to extraordinary ages. For example, the longevity of Pacific rockfish (Sebastes) increases exponentially with the deepest occurrence of a species, and the deepest living species can reach 200 years old (Cailliet et al., 2001). Orange roughy Hoplostethus atlanticus have been recorded to 150 years old, and they can't reproduce until their mid-twenties (Branch, 2001). These life history characteristics make deep-sea fish extremely vulnerable to over-exploitation.

Few deep-sea species are marketable. They are adapted to life without waves and most experience only weak currents. This means their flesh is soft and their scales are easily stripped by fishing gear. Fishing in the deep sea produces large quantities of by-catch of which $100 \%$ dies (Merrett \& Haedrich, 1997).

The absurdities of fishing in the deep sea go far beyond removing fish. Fisheries target areas of great biological significance, including seamounts, steep slopes, such as those of canyon walls, and hard bottoms (Roberts, 2002) which, unlike most of the deep-sea, are not covered in sediment. In these places strong currents sweep away sediment and bring food which, in addition to the large fish aggregations that attract fishers, supports 
a rich benthic fauna of suspension feeding animals, including corals, sponges, seafans and hydroids (WWF/ IUCN, 2001). It is only in the last decade or so that we have discovered remarkable coral reef communities in the North Atlantic's deep cold waters. These reefs support hundreds, perhaps thousands of species (M.J. Roberts, 1997), but trawling has already devastated many. For example, $30-50 \%$ of Norway's deep-water coral beds have been seriously damaged or destroyed by trawling (Fossa et al., 2002). Bizarre and beautiful fields of glass sponges have been trawled to oblivion along North America's eastern seaboard. In the Southern Ocean, seamounts that once supported lush forests of invertebrates have been stripped to bare rock by a few decades of trawling for orange roughy (Koslow et al., 2001).

The biology of deep-sea organisms compels us to rethink our attitudes to exploitation. Deep-sea fish stocks must be considered as non-renewable resources and fishing the deep must be seen as mining the sea. At the moment we are removing species faster than they can possibly replace themselves (Merrett \& Haedrich, 1997). Many fishers tacitly acknowledge this fact by targeting fish spawning aggregations. This allows them to achieve big catches and gain swift profits, but in doing so they are destroying populations (Roberts, 2002; see Johannes, 1998, for shallow water examples) and having to constantly move on in search of undiscovered and unexploited aggregations. The deep sea is the planet's last frontier for human expansion and appropriation. Here our terrestrial experience is being played out one final time as we eliminate our deep-water megafauna, and leave their habitats in ruins. Because deep-sea life is so vulnerable, only complete protection will save it from the damage wrought by fishing.

\section{Differences in attitude towards sea and land}

Throughout this paper I have argued that humans have damaged marine ecosystems in ways that are comparable to our impacts on the land. But there is an important difference in our attitude towards land and sea: marine life is almost solely valued for commerce We allow marine organisms to be exploited in ways that would now be unthinkable on land, and the agencies responsible for this exploitation are given management supremacy. In the United States, for example, the National Oceanic and Atmospheric Administration (NOAA), the body responsible for fisheries, is part of the Department of Commerce. Because NOAA also manages the National Marine Sanctuaries, they too fall under the remit of Commerce. These sanctuaries struggle under a dual mandate to protect the nation's most impressive marine habitats, and to allow commercial fisheries exploitation. This is seen by many as central to why most marine sanctuaries fail to provide safe havens for species or habitats (NRC, 2001). Similarly in Europe, when it comes to the sea, the voices of fisheries ministers always sound more stridently than those of environment ministers.

The paucity of marine protected areas is an eloquent testimonial of the difference in our attitudes. Less than half a percent of the oceans lie within protected areas (Kelleher et al., 1995), and Roberts \& Hawkins (2000) estimate that only one ten thousandth of the sea is protected from all fishing. This highlights our utilitarian attitude towards the ocean. In a press release of December 2001, Britain's Department for Environment, Food and Rural Affairs (DEFRA) proudly declared that they would soon act to protect the Darwin Mounds, an area of deepsea coral habitat off Scotland that is being destroyed by trawling. DEFRA's pride stemmed from the fact that this would be the first use of the European Habitats Directive to protect offshore areas within the 200 nautical mile Exclusive Economic Zone. They didn't mention that losing a court case to Greenpeace forced them to take this step, nor exactly what protection measures they would take. Although protection from trawling is an obvious necessity, restricting fishing effort remains almost unmentionable in government circles. As of writing this paper, April 2003, the British Government has still not implemented protection, despite the fact that a single pass of a trawl can wipe out an entire mound.

In a similar vein, a high profile marine stewardship report titled Safeguarding Our Seas was released in Britain by DEFRA in 2002 (DEFRA, 2002). It is long on worthy statements about the importance of the seas and the growing need for their protection, but short on specifics as to what should be done. Rather than being viewed as a primary cause of degradation to the marine environment, fishing is treated simply as a process that needs to be better controlled to optimize catches. Quotas are promoted as the sole mechanism for delivering sustainable fisheries despite the abject failure of quota management to prevent stock declines (Roberts, 2000). In the same year this report was issued, scientists charged with managing Europe's fish stocks recommended to the European Union that the cod fishery be closed. Yet there is no suggestion in DEFRA's report that the decline in abundance of this species is a conservation concern as well as an economic worry. On land, similar declines in populations of farmland birds or butterflies cause alarm and galvanize conservation action. Sadly, it seems that many people still feel that fish are not wildlife, that habitats we cannot see or visit easily are not important, and that conservation in the sea means, well, not very much at all. If British views were an isolated pocket of 
folly in a European sea of enlightenment, then things might not be so bad. Unfortunately, Britain is representative of the views that prevail throughout Europe and in many countries beyond.

\section{A new agenda for the oceans}

Safeguarding Our Seas (DEFRA, 2002) makes not a single mention of marine reserves, areas that are permanently off limits to all fishing. It is a telling omission given the growing body of evidence worldwide that reserves are effective in protecting species and habitats and that they could play a major role in sustaining fisheries (Mosquera et al., 2000; Roberts \& Hawkins, 2000; NRC, 2001; Roberts et al., 2001). Marine reserves work in a very straightforward way. By protecting animals from capture, they allow them to live longer, grow larger and become more numerous (Bohnsack, 1998). Reserves thus provide refuges for reproductive stocks that can supply surrounding fishing grounds with eggs and larvae via ocean currents. In addition juveniles and adult fish can spillover from reserves. Because big fish produce many times more offspring than small fish, reserves can make disproportionately large contributions to population replenishment relative to their area (Bohnsack, 1998).

The conservation values of reserves are becoming well established through repeated demonstration in many different ecological and geographical settings (see recent reviews by Roberts \& Hawkins, 2000; NRC, 2001; Halpern \& Warner, 2002; Palumbi, 2002; Halpern, 2003). Reserves can achieve much more than present fishery management approaches can alone. Critically, they protect habitats from damage by fishing gear such as trawls. Simply reducing fishing effort cannot offer sufficient protection to sensitive habitats such as coldwater coral beds (Hall-Spencer et al., 2002). Because recovery times for such habitats are measured in decades to centuries, a change in trawling frequency from perhaps two to one passes per year will be insignificant. Only outright protection can allow recovery and safeguard habitat integrity.

A second conservation benefit that reserves offer over conventional fishery management is that they allow highly vulnerable species to persist. Fisheries of even modest intensity can extirpate species such as skates, groupers, sharks and molluscs (C.M. Roberts, 1997; Casey \& Myers, 1998; Roberts \& Hawkins, 1999; Dulvy \& Reynolds, 2002). Scaling back fishing intensity to protect such species would reduce production from more resilient species, and so is considered undesirable. Putting some areas off-limits to fishing achieves the necessary balance between protection and exploitation without sacrificing yields from productive species.
Reserves can also increase resilience of populations to environmental variability in ways that conventional fishery management cannot. Modern fisheries have reduced to a handful the number of reproductively active age classes of potentially long-lived species such as cod and halibut Hippoglossus spp. (Longhurst, 2002). This leaves populations highly vulnerable when years are poor for offspring survival. One of the probable reasons many marine species evolved long life spans is to see them through such periods. Reserves foster the development of natural, extended age structures that help populations persist.

Working reserves around the world provide dramatic testimony of their effectiveness. Populations of exploited species often rebound rapidly, increasing in biomass by $2-3$ times within a few years of protection. Some species reach levels of abundance in reserves an order of magnitude or more above those in nearby exploited regions. After 20 years of protection, snappers Pagrus auratus became 6-9 times more abundant in New Zealand's Leigh Marine Reserve compared to fishing grounds (Babcock et al., 1999). Numbers of bastard trumpeter fish Latridopsis forsteri increased more than 100 times over 6 years of protection in Tasmanian reserves (Edgar \& Barrett, 1999). After 25 years of protection, densities of an endemic bream Chrysoblephus laticeps were over 40 times greater in South Africa's Tsitsikamma marine reserve than in fished areas nearby (Buxton \& Smale, 1989). After 15 years of protection, individuals of the lunartail grouper Variola louti were three times as heavy on average in the Ras Mohammed Marine Park in the Red Sea as in fishing grounds (Roberts \& Polunin, 1993). In New Zealand's Tonga Island Marine Reserve, large male spiny lobsters Jasus edwardsii reached densities 10 times greater in reserves than in fishing grounds within 5 years of receiving protection, and the egg output from reserves was estimated to be 9 times greater (Davidson et al., 2002). As well as proving reserves work, the magnitude of differences that develop between protected areas and fishing grounds reveal the scale of fishing impacts on marine ecosystems.

Evidence that reserves can enhance fisheries is accumulating fast (Gell \& Roberts, 2003). Spillover of animals from marine reserves has been demonstrated in more than a dozen countries worldwide. The first indication that reserves are supplying fisheries often comes from changes in patterns of fishing. After a few years of reserve protection, fishers may begin to concentrate fishing effort close to reserve boundaries in a process called 'fishing-the-line'. Experimental measures of fish catches in several regions of the world have confirmed predictions of higher catch rates. In coral reef fisheries of St Lucia, catches increased by $46-90 \%$, and 
in Egypt by $66 \%$ around networks of marine reserves after 5 years of protection (Roberts et al., 2001; Galal et al., 2002). In the Philippines, catch-per-unit-effort in a hook and line fishery has increased 10 fold around the Apo Island reserve, while catches in areas without reserves have fallen (Maypa et al., 2002). Fishery effects of reserves also scale up to industrial fisheries. On Georges Bank off the US east coast three areas totaling $17,000 \mathrm{~km}^{2}$ were closed to fishing in 1995 . This was done to protect bottom-living fish and scallops, but it has also rejuvenated the scallop fishery (Murawski et al., 2000). Spawning by protected scallops is replenishing populations outside reserves (see PISCO, 2002, and Gell \& Roberts, 2003, for summaries of the evidence).

Few conservation biologists now believe that adequate protection of marine life can be achieved without marine reserves (Scientific Consensus Statement on Marine Reserves and Marine Protected Areas, 2002), but implementation of new protected areas remains slow. Rates of increase in threats to the oceans suggest that urgent action is imperative. Although the attitudes of some decision makers seem to belong in a former age, there is hope for progress because the views of the general public are often more progressive. American surveys in 2001 found that on average, people thought about $22 \%$ of the sea was already protected from all fishing (Seaweb, 2003). Most respondents reported that they were angry or very angry to hear almost none of the sea receives this level of protection, and that hardly any fully protected marine reserves exist. Seventy five percent felt that more marine reserves were needed. The time is ripe for change.

Our recent experiences with marine reserves offer us an extraordinary and humbling lesson. We can get more out of the sea by leaving some of it alone. This lesson is being learned painfully, place-by-place, as fisheries collapse and marine ecosystems degrade, taking with them the livelihoods of fishing communities and the splendour of aquatic life. We can obtain more seafood not by creating enormous aquaculture facilities and in the process destroying marine habitats to make way for them (Naylor et al., 1998, 2000), but by simply allowing our oceans space to produce it. In essence, reserves could help us turn back the clock by 200 years as they replace critical fish refuges that have been whittled away by fishing.

Protecting areas of the sea and coast in marine reserves represents an exceptionally simple, low cost way of securing the future for fish, for those who catch them, and for those who rely on them and enjoy them for food. Combined with the best of existing management tools, marine reserves will allow us to harness the productive potential of the sea far more effectively than our present, piecemeal approaches to fishery manage- ment do. Theoretical work suggests that reserves will deliver the greatest fishery benefits when they are established in networks covering $20-40 \%$ of the oceans (NRC, 2001). Such networks would also provide a firm foundation for the restoration and sustenance of marine biodiversity (Roberts et al., 2001; Palumbi, 2002). Our options for creating such large protected areas on land are greatly constrained by patterns of human ownership, occupation and use, and because protection competes head on with exploitation. The sea provides an outstanding opportunity to implement reserves in the simultaneous service of conservation and exploitation, and because there are hardly any reserves in the sea, we have a blank slate upon which to work.

\section{Acknowledgements}

I gratefully acknowledge the The Pew Charitable Trusts for their support and Julie Hawkins for long discussions about marine conservation and her helpful comments on the manuscript.

\section{References}

Angel, M.V. (1993) Biodiversity of the pelagic ocean. Conservation Biology, 7, 760-72.

Auster, P.J. \& Langton, R.W. (1999) The effects of fishing on fish habitat. American Fisheries Society Symposium, 22, 150-187.

Babcock, R.C., Kelly, S., Shears, N.T., Walker, J.W. \& Willis, T.J. (1999) Changes in community structure in temperate marine reserves. Marine Ecology Progress Series, 189, 125-134.

Bohnsack, J.A. (1998) Application of marine reserves to reef fisheries management. Australian Journal of Ecology, 23, 298-304.

Bradshaw, C., Veale, L.O., Hill, A. S. \& Brand, A.R. (2001) The effect of scallop dredging on Irish Sea benthos: experiments using a closed area. Hydrobiologia, 465, 129-138.

Branch, T.A. (2001) A review of Orange Roughy Hoplostethus atlanticus fisheries, estimation methods, biology and stock structure. South African Journal of Marine Science, 23, 181-203.

Brashares, J.S., Arcese, P. \& Sam, M.K. (2001) Human demography and reserve size predict wildlife extinction in West Africa. Proceedings of the Royal Society of London B, 268, 2473-2478.

Burkholder, J.M., Mallin, M.A. \& Glasgow, H.B. (1999) Fish kills, bottom-water hypoxia, and the toxic Pfiesteria complex in the Neuse River and estuary. Marine Ecology Progress Series, 179, 301-310.

Buxton, C.D. \& Smale, M.J. (1989) Abundance and distribution patterns of three temperate marine reef fish (Teleostei: Sparidae) in exploited and unexploited areas off the southern cape coast. Journal of Applied Ecology, 26, $441-451$. 
Bythell, J. \& Sheppard, C. (1993) Mass mortality of Caribbean shallow corals. Marine Pollution Bulletin, 26, 296-297.

Cailliet, G.M., Andrews, A.H., Burton, E.J., Watters, D.L., Kline, D.E. \& Ferry-Graham, L.A. (2001) Age determination and validation studies of marine fishes: do deep-dwellers live longer? Experimental Gerontology, 36, 739-764.

Carlton, J.T., Geller, J.B., Reaka-Kudla, M.L. \& Norse, E.A. (1999) Historical extinctions in the sea. Annual Review of Ecology and Systematics, 30, 515-538.

Casey, J.M. \& Myers, R.A. (1998) Near extinction of a large, widely distributed fish. Science, 281, 690-692.

Christensen, V., Guénette, S., Heymans, J.J., Walters, C.J., Watson, R., Zeller, D. \& Pauly, D. (2003) Hundred-year decline of North Atlantic predatory fishes. Fish and Fisheries, $4,1-24$.

Collie, J.S., Escanero, G.A. \& Valentine, P.C. (1997) Effects of bottom fishing on the benthic megafauna of Georges Bank. Marine Ecology Progress Series, 155, 159-172.

Cushing, D.H. (1988) The Provident Sea. Cambridge University Press, Cambridge, UK.

Dampier, W. (1697) A New Voyage Round the World. Dover Publications, New York, USA (1968).

Davidson, R.J., Villouta, E., Cole, R.G. \& Barrier, R.G.F. (2002) Effects of marine reserve protection on spiny lobster (Jasus edwardsii) abundance and size at Tonga Island Marine Reserve, New Zealand. Aquatic Conservation and Freshwater Ecosystems, 12, 213-227.

De Forges, B.R., Koslow, J.A. \& Poore, G.C.B. (2000) Diversity and endemism of the benthic seamount fauna in the southwest Pacific. Nature, 405, 944-947.

DEFRA (2002) Safeguarding Our Seas: A Strategy for the Conservation and Sustainable Development of Our Marine Environment. Department for Environment, Food and Rural Affairs, UK Government, London, UK.

Done, T.J. (1992) Phase-shifts in coral reef communities and their ecological significance. Hydrobiologia, 247, 121-132.

Dulvy, N.K. \& Reynolds, J.D. (2002) Predicting extinction vulnerability in skates. Conservation Biology, 16, 440-450.

Dulvy, N.K., Sadovy, Y. \& Reynolds, J.D. (in press) Extinction vulnerability in marine populations. Fish and Fisheries.

Edgar, G.J. \& Barrett, N.S. (1999) Effects of the declaration of marine reserves on Tasmanian reef fishes, invertebrates and plants. Journal of Experimental Marine Biology and Ecology, 242, 107-144.

FAO (Food and Agriculture Organization of the United Nations) (2000) Technical Consultation on the Suitability of the CITES Criteria for Listing Commercially-Exploited Aquatic Species. Food and Agriculture Organisation of the United Nations, Rome, Italy, FI:SLC /2000/2.

Fleming, L.E., Easom, J., Baden, D., Rowan, A. \& Levin, B. (1999) Emerging harmful algal blooms and human health: Pfiesteria and related organisms. Toxicologic Pathology, 27, 573-581.

Fossa, J.H., Mortensen, P.B. \& Furevik, D.M. (2002) The deep-water coral Lophelia pertusa in Norwegian waters: distribution and fishery impacts. Hydrobiologia, 471, $1-12$
Galal, N., Ormond, R.F.G. \& Hassan, O. (2002) Effect of a network of no-take reserves in increasing exploited reef fish stocks and catch per unit effort at Nabq, South Sinai, Egypt. Marine and Freshwater Research, 53, 199-205.

Gell, F.R. \& Roberts, C.M. (2003) The Fishery Effects of Marine Reserves and Fishery Closures. WWF-US, Washington, DC, USA [also available from http:/ / www.worldwildlife.org/ oceans/fishery_effects.pdf, accessed 14 April 2003].

Hall-Spencer, J., Allain, V. \& Fossa, J.H. (2002) Trawling damage to Northeast Atlantic ancient coral reefs. Proceedings of the Royal Society of London B, 269, 507-511.

Halpern, B. (2003) The impact of marine reserves: do reserves work and does size matter? Ecological Applications, 13 Supplement, S117-S137.

Halpern, B.S. \& Warner, R.R. (2002) Marine reserves have rapid and lasting effects. Ecology Letters, 5, 361-366.

Harvell, C.D., Kim, K., Burkholder, J.M., Colwell, R.R., Epstein, P.R., Grimes, D.J., Hofmann, E.E., Lipp, E.K., Osterhaus, A.D.M.E., Overstreet, R.M., Porter, J.W., Smith, G.W. \& Vasta, G.R. (1999) Emerging marine diseases climate links and anthropogenic factors. Science, 285, 1505-1510.

Hawkins, J.P. \& Roberts, C.M. (in press) Effects of artisanal fishing on Caribbean coral reefs. Conservation Biology.

Hoegh-Guldberg, O. (1999) Climate change, coral bleaching and the future of the world's coral reefs. Marine and Freshwater Research, 50, 839-866.

Hutchings, J.A. (2000) Collapse and recovery of marine fishes. Nature, 406, 882-885.

Hutchings, J.A. (2001) Influence of population decline, fishing, and spawner variability on the recovery of marine fishes. Journal of Fish Biology, 59 (Supplement A), 306-322.

IUCN (2001) The IUCN Red List of Threatened Species: 2001 Categories \& Criteria (version 3.1). http:/ / www.redlist.org/ info/categories_criteria2001.html [accessed 14 April 2003].

Jackson, J.B.C. (1997) Reefs since Columbus. Coral Reefs, S16, S23-S32.

Jackson, J.B.C., Kirby, M.X., Berger, W.H., Bjorndal, K.A., Botsford, L.W., Bourque, B.J., Bradbury, R.H., Cooke, R., Erlandson, J., Estes, J.A., Hughes, T.P., Kidwell, S., Lange, C.B., Lenihan, H.S., Pandolfi, J.M., Peterson, C.H., Steneck, R.S., Tegner, M.J. \& Warner, R.R. (2001) Historical overfishing and the recent collapse of coastal ecosystems. Science, 293, 629-638.

Jennings, S., Kaiser, M.J. \& Reynolds, J.D. (2001) Marine Fisheries Ecology. Blackwell Science, Oxford, UK.

Johannes, R.E. (1998) The case for data-less marine resource management: examples from tropical nearshore finfisheries. Trends in Ecology and Evolution, 13, 243-246.

Kelleher, G., Bleakley, C. \& Wells, S. (eds) (1995) A Global Representative System of Marine Protected Areas. Volumes I-IV. The Great Barrier Reef Marine Authority, The World Bank and IUCN. Environment Department, The World Bank, Washington, DC, USA.

Knowler, D. \& Barbier, E.B. (2000) The economics of an invading species: a theoretical model and case study application. In The Economics of Biological Invasions. (eds C. Perrings, M. Williamson \& S. Dalmazzone), pp. 70-93. Edward Elgar, Cheltenham, UK. 
Koslow, J.A., Boehlert, G.W., Gordon, J.D.M., Haedrich, R.L., Lorance, P. \& Parin, N. (2000) Continental slope and deepsea fisheries: implications for a fragile ecosystem. ICES Journal of Marine Science, 57, 548-557.

Kurlansky, M. (1997) Cod: a Biography of the Fish that Changed the World. Jonathan Cape, London, UK.

Lenihan, H.S. \& Peterson, C.H. (1998) How habitat degradation through fishery disturbance enhances impacts of hypoxia on oyster reefs. Ecological Applications, 8, 128-140.

Lindholm, J.B., Auster, P.J. \& Kaufman, L.S. (1999) Habitatmediated survivorship of juvenile (0-year) Atlantic cod Gadhus morhua. Marine Ecology Progress Series, 180, 247-255.

Longhurst, A. (2002) Murphy's law revisited: longevity as a factor in recruitment to fish populations. Fisheries Research, 56, 125-131.

Maypa, A.P., Russ, G.R., Alcala, A.C. \& Calumpong, H.P. (2002) Long-term trends in yield and catch rates of the coral reef fishery at Apo Island, Central Philippines. Marine and Freshwater Research, 53, 207-213.

McAllister, D.E., Baquero, J., Spiller, G. \& Campbell, R. (1999) A Global Trawling Ground Survey. Marine Conservation Biology Institute, World Resources Institute and Ocean Voice International, Ottawa, Canada.

Merrett, N.R. \& Haedrich, R.L. (1997) Deep-sea Demersal Fish and Fisheries, Chapman and Hall, London, UK.

Mosquera, I., Côté, I.M., Jennings, S. \& Reynolds, J.D. (2000) Conservation benefits of marine reserves for fish populations. Animal Conservation, 4, 321-332.

Murawski, S.A., Brown, R., Lai, H.-L., Rago, P.J. \& Hendrickson, L. (2000) Large-scale closed areas as a fisheries management tool in temperate marine systems: the Georges Bank experience. Bulletin of Marine Science, 66, 775-798.

Musick, J.A. (1999) Criteria to define extinction risk in marine fishes. Fisheries, 24, 6-14.

Naylor, R.L., Goldburg, R.J., Mooney, H., Beveridge, M., Clay, J., Folke, C., Kautsky, N., Lubchenco, J., Primavera, J. \& Williams, M. (1998) Nature's subsidies to shrimp and salmon farming. Science, 282, 883-884.

Naylor, R.L., Goldburg, R.J., Primavera, J.H., Kautsky, N., Beveridge, M.C.M., Clay, J., Folke, C., Lubchenco, J., Mooney, H. \& Troell, M. (2000) Effect of aquaculture on world fish supplies. Nature, 405, 1017-1024.

NRC (National Research Council) (2001) Marine Protected Areas. Tools for Sustaining Ocean Ecosystems. National Academy Press, Washington, DC, USA.

Palumbi, S.R. (2002) Marine Reserves: A Tool for Ecosystem Management and Conservation. Pew Oceans Commission, Arlington, USA.

Pimm, S.L. \& Raven, P. (2000) Biodiversity - extinction by numbers. Nature, 403, 843-845.

PISCO (2002). The Science of Marine Reserves. Partnership for Interdisciplinary Studies of Coastal Oceans. http://www.piscoweb.org/outreach/events/ mediaworkshops/edge-research-report.pdf

Precht, W.F., Bruckner, A.W., Aronson, R.B. \& Bruckner, R.J. (2002) Endangered acroporid corals of the Caribbean. Coral Reefs, 21, 41-42.

Reynolds, J.D., Dulvy, N.K. \& Roberts, C.M. (2002) Exploitation and other threats to fish conservation. In Handbook of Fish Biology and Fisheries: Volume 2, Fisheries (eds P.J.B. Hart \& J.D. Reynolds), pp. 319-341. Blackwell, Oxford, UK.
Roberts, C.M. (1997) Ecological advice for the global fisheries crisis. Trends in Ecology and Evolution, 12, 35-38.

Roberts, C.M. (2000) Why does fishery management so often fail? In Science and Environmental Decision Making (eds M. Huxham \& D. Sumner), pp. 170-192. Prentice Hall, London, UK

Roberts, C.M. (2002) Deep impact: the rising toll of fishing in the deep sea. Trends in Ecology and Evolution, 17, 242-245.

Roberts, C.M. \& Hawkins, J.P. (1999) Extinction risk in the sea. Trends in Ecology and Evolution, 14, 241-246.

Roberts, C.M. \& Hawkins, J.P. (2000) Fully-protected Marine Reserves: A Guide. WWF Endangered Seas Campaign, Washington, DC, USA and University of York, UK [also available from http:/ / www.panda.org/resources/ publications / water/mpreserves/mar_dwnld.htm, accessed 14 April 2003].

Roberts, C.M. \& Polunin, N.V.C. (1993) Effects of marine reserve protection on northern Red Sea fish populations. Proceedings of the 7th International Coral Reef Symposium, Guam, 2, 969-977.

Roberts, C.M., Bohnsack, J.A., Gell, F.R., Hawkins, J.P. \& Goodridge, R. (2001) Effects of marine reserves on adjacent fisheries. Science, 294, 1920-1923.

Roberts, C.M., McClean, C.J., Veron, J.E.N., Hawkins, J.P., Allen, G.R., McAllister, D.E., Mittermeier, C.G., Schueler, F.W., Spalding, M., Wells, F., Vynne, C. \& Werner, T.B. (2002) Marine biodiversity hotspots and conservation priorities for tropical reefs. Science, 295, 1280-1284.

Roberts, M.J. (1997) Coral in deep water. New Scientist, 155, 40-43.

Rose, G.A. (1993) Cod spawning on a migration highway in the north-west Atlantic. Nature, 366, 458-461.

Rose, G.A. \& O'Driscoll, R.L. (2002) Capelin are good for cod: can the northern stock rebuild without them? ICES Journal of Marine Science, 59, 1018-1026.

Seaweb (2003) http:/ / www.seaweb.org [accessed 14 April 2003].

Scientific Consensus Statement on Marine Reserves and Marine Protected Areas (2002) http:/ / www.compassonline.org/ activities/2002/consensus.pdf [accessed 14 April 2003].

Smedbol, R.K. \& Wroblewski, J.S. (2002) Metapopulation theory and northern cod population structure: interdependency of subpopulations in recovery of a groundfish population. Fisheries Research, 55, 161-174.

Spalding, M.D., Blasco, F. \& Field, C.D. (1997) World Mangrove Atlas. International Society for Mangrove Ecosystems, Okinawa, Japan.

Steller, G.W. (1743) Journal of a Voyage with Bering, 1741-1742. Translated by M.A. Engel and O.W. Frost. Stanford University Press, Stanford, USA (1988).

Thornton, D.C.O., Santillo, D. \& Thake, B. (1999) Prediction of sporadic mucilaginous algal blooms in the northern Adriatic Sea. Marine Pollution Bulletin, 38, 891-898.

Van Dover, C.L., German, C.R., Speer, K.G., Parson, L.M. \& Vrijenhoek, R.C. (2002) Evolution and biogeography of deep-sea vent and seep invertebrates. Science, 295, 1253-1257. 
Watling, L. \& Norse, E.A. (1998) Disturbance of the sea bed by mobile fishing gear: a comparison to forest clearcutting. Conservation Biology, 12, 1180-1197.

Wells, S.M. (1997) Giant clams: Status, Trades and Mariculture, and the Role of CITES in Management. IUCN, Gland, Switzerland and Cambridge, UK.

Wilkinson, C.R. (2000) The Status of Coral Reefs of the World: 2000. Australian Institute of Marine Sciences, Global Coral Reef Monitoring Network, Townsville, Australia.

Wing, S.R. \& Wing, E.S. (2001) Prehistoric fisheries in the Caribbean. Coral Reefs, 20, 1-8.

WWF/IUCN (2001) The Status of Natural Resources on the HighSeas, WWF and IUCN, Gland, Swtizerland.

Zimmerman, A.R. \& Canuel, E.A. (2000) A geochemical record of eutrophication and anoxia in Chesapeake Bay sediments: anthropogenic influence on organic matter composition. Marine Chemistry, 69, 117-137.

\section{Biographical sketch}

Callum Roberts' research focuses on threats to marine ecosystems and species, and on finding the means to protect them. His work includes studies of the profound historical and recent alteration of marine ecosystems by fishing, on the extinction risk of marine species and on global conservation priorities for coral reefs. Recently, he published a paper highlighting the imminent danger from fishing to life in the deep sea - the Earth's final wilderness frontier. His bestknown work is on the performance and design of marine reserves, areas that are protected from all fishing. His studies show that all is not lost - if we can find the will, we have the means to protect ocean life, and carry on eating fish too! 